Article

\title{
The Mission of Early Childhood Education in the Anthropocene
}

\author{
Lili-Ann Wolff ${ }^{1, *}$, Tuula H. Skarstein ${ }^{2}$ (D) and Frode Skarstein ${ }^{3}$ (D) \\ 1 Faculty of Educational Sciences, University of Helsinki, P.O. Box 9, 00014 Helsinki, Finland \\ 2 Department of Early Childhood Education, University of Stavanger, 4036 Stavanger, Norway; \\ tuula.skarstein@uis.no \\ 3 Department of Education and Sports Science, University of Stavanger, 4036 Stavanger, Norway; \\ frode.skarstein@uis.no \\ * Correspondence: lili-ann.wolff@helsinki.fi; Tel.: +358-50-4487088
}

Received: 17 December 2019; Accepted: 21 January 2020; Published: 23 January 2020

\begin{abstract}
During the last century, the human way of life has begun to transgress many of the Earth's biophysical boundaries in an alarming way. The consequences of this are more dramatic and long lasting than ever before. Many researchers even argue that humanity has created a new geological epoch, which they call Anthropocene. Education, even in early childhood (EC), is often presented as a remedy for these complex problems. Yet, how can anyone prepare young children to deal with such tremendous changes? The primary aim of our study is to define and outline what the mission of early childhood education (ECE) might be in the epoch of the Anthropocene. Through a comprehensive review of the literature, we have tried to find answers about how the Anthropocene could be addressed in ECE. We have searched for answers in the natural science literature, policy documents, educational research articles and philosophy, and discuss the various standpoints we have identified. We argue that the Anthropocene demands a new, more authentic education; a change towards a more holistic, transformative, sustainability-oriented approach. At the same time, children, as always, have a right to a safe, positive and encouraging childhood.
\end{abstract}

Keywords: early childhood education (ECE); Anthropocene; sustainability; sustainability education; 21st century skills; outdoor education; children's agency; practice architecture; posthumanistic approaches

\section{Introduction}

In 1972, the Club of Rome published Limits to Growth, a text which questioned the viability of continued economic growth [1]. Since then, sustainability has been a contentious issue in local, regional and international policy. One of the latest signs of this is the 2030 Agenda for Sustainable Development, adopted by all United Nations member states in 2015. The core of this agenda is the 17 Sustainable Development Goals (SDGs) [2]. However, there are also movements and voices saying that these goals are not radical enough, but only promote the status quo. Ecological justice movements in the global south and degrowth movements in the north share many matters of concern [3]. They question dominant societal capitalist models and request a redistribution of wealth, [3] and a reduction in economic activities in the form of production and consumption, as well as a change in the way societies organise themselves [4]. Therefore, activists inspire and promote transformation to reduce common forms of domination [3]. The worldwide student-led climate protests clearly show that young people are tired of waiting for the results of political climate negotiations and want to experience more radical action. Still, international and national education policy in many countries stresses economic growth [5]. 
Similar to other educational plans, the policy plans for early childhood education (ECE) are filled with goals, duties and outlines for teaching and learning in nurseries and preschools. In recent years, Nordic countries (among many others) have included sustainable development and the promotion of sustainable lifestyles as significant goals of ECE. In Finland, sustainability is emphasised in the national core curriculum for early childhood education and care [6,7], and it is also stressed as an aim in the Finnish Act on Early Childhood and Care (Varhaiskasvatuslaki 540/2018 § 3.8). In the Norwegian National Framework Plan for Kindergartens, sustainable development is defined as one of the core values of kindergartens, which "shall be promulgated, practiced and manifest in every aspect of a kindergarten's pedagogical practices". [8] (p. 7)

Nevertheless, there are few (if any) words in the policy documents about the most worrying and unpredictable issue of today, namely human-induced climate change. Likewise, few educators are experts in climate change. The teaching of this topic requires utmost care and consideration, since young people might react with anxiety [9], but it is too late to deny the whole process. According to Preiser, Pereira and Biggs [10] (p. 86), humans need to start "navigating the future-as-Anthropocene." It is totally irresponsible to continue to treat the climate crisis like something that will happen elsewhere at some time in the future, outside human egocentrism and comfort zones [11]. It is a considerable part of human life, with consequences for both the present and the future.

"Whatever climate change is, it is going to be unpredictable. And it's going to get that way during my lifetime ... While I'm likely to see some dramatic changes, it's the kids being born now that will really feel it. What sort of world will a six-year-old today grow up in? One radically different to the one I've known." [12] (p. 9)

Despite the gloomy scenario described by Rawson and Whitmore, they are not completely pessimistic. They advise their readers not to panic, but rather to start preparing. Hamilton [11] argues that one cannot prepare for something without being aware of it. Therefore, he asks for a cognitive leap, a shift from merely focusing on humans and the human culture, to focusing on the earth's systems and human influence on these systems.

However, the discussion on how to educate people to handle this wicked problem is not the main topic in the contemporary education debate. Instead, one of the main topics when discussing future education is often the digitalisation of preschools and schools [13]. This focus is also obvious in the much mentioned "21st century skills", a skill set developed and mostly aimed at enabling children to cope with emerging technologies and the consequences these will have on our lives [14]. Digital learning is also a discussion topic in the international OECD document, Helping our youngest to grow [15]. Digital skills are undoubtedly vital in the 21st century and are a part of preparing children for the Anthropocene. However, it is important to discuss whether or not they are the most crucial skills. Likewise, it is important to be aware of the challenges of an uncritical digitising of education and to consider the necessity of digital resilience [16]. Compared to the challenges of digital efforts in educational settings, the Anthropocene might be a much greater epochal key issue [17].

\section{Aim and Method}

Our primary aim in this study is to define and outline what the mission of early childhood education might be in the epoch of Anthropocene. The research questions are:

1. What knowledge will prepare young children to live in the Anthropocene?

2. Which skills will prepare young children to live in the Anthropocene?

3. What should the value base of ECE be in the Anthropocene?

We have reviewed the literature for conceptual explanations and suggestions on how the challenge of the Anthropocene could be addressed in ECE. Using recent academic articles, books and policy documents, we have searched for answers to those questions. We have chosen to focus on the literature from three categories: (1) literature about the Anthropocene, (2) recent international and national 
literature on education, and (3) literature about how sustainability and the concept of the Anthropocene is, or should be, addressed in education, especially ECE. Our focus is on the newest, more relevant articles, books and documents that we consider most suitable to stimulate a discussion on the topic.

We have included 38 books (monographies), 78 academic articles and chapters in anthologies, and 14 policy documents in our study. About $20 \%$ of the publications deal with the topic Anthropocene, nearly $25 \%$ with current topics in education, and more than $40 \%$ of the publications concern the implementation of sustainability in education. Of the last category, $60 \%$ deal with ECE. More specifically, $27 \%$ of all the publications concern sustainability in ECE. The rest of the publications include the topics of sustainability in general and philosophy, as well as interdisciplinary topics. All the books and articles are from the academic literature, and three of the EC sustainability education articles are reviews of many other articles. Since our literature review has been limited by the access to the literature of our respective university libraries, most of the literature has been in English. For this reason, the result is biased; we have not presented a globally-based result. The main sources of the literature are from the USA, Europe (mainly UK and the Nordic countries) and Australia. We have only a few sources from Latin America, Africa, and Asia. Based on the literature we have described, we have discussed, compared and combined the various views of the authors and communicated our own standpoint.

\section{The Challenges of the Anthropocene}

The Anthropocene is a concept that was first suggested by Crutzen and Stoermer [18] to define a geologic time period following the Holocene and to emphasise the strong human-influenced (anthropogenic) changes to Earth's geology and ecology. Humankind has started to cause remarkable changes in the atmospheric, geologic, hydrologic, biospheric and other earth systems, which have impacts reaching far beyond the physical spheres.

\subsection{The Consequences of the Anthropocen}

There have been many discussions about the term Anthropocene since Crutzen and Stoermer [18] first suggested it. Likewise, there is no consensus yet regarding when the Anthropocene began: was it already there at the advent of agriculture? At the onset of the industrial revolution in the 18th century? Or was it at the great acceleration of population growth and industrialisation after the Second World War [19-21]? Waters et al. [21] suggest that, based on deposits of new materials and radionuclides and human-caused modification of sedimentary processes, the beginning of the Anthropocene should be sometime in the mid-20th century. One often suggested starting point is the detonation of the Trinity nuclear bomb at Alamogordo in 1945, marking the beginning of the use of nuclear weapons and the accumulation of radioactive fallout [19-21].

Independent of the starting point, the consequences of the Anthropocene are severe. All components of the global environment are influenced. In this epoch, oceans, coastal zones, the atmosphere and land areas are all threatened [22]. The changes are not analogous to predicted climate changes or earlier experiences, and thus are not predictable. Several studies have reported on the ongoing global sixth mass extinction event consisting of immense anthropogenic decline in biodiversity. This has severe consequences for ecosystems, and therefore also ecosystem services essential for human existence [23]. Humans are upsetting the indispensable global cycling of elements necessary for life on Earth, and thus affecting nearly every living creature [24]. Even if we often talk about humans as a general entity in this article, it is important to stress that it is not general humanity that causes the severe changes to the Earth, but many different groups produce different problems [24]. Likewise, different age groups in different parts of the world will experience the changes differently.

As a group, children in particular will suffer from climate change. They are both physically and psychologically vulnerable to abnormal weather disasters that will cause food, water, and nutrient insecurity in vulnerable regions $[25,26]$. Children are also inherently more sensitive than adults to sudden weather changes, since they cannot adapt to rainstorms, snowstorms, heat waves, and other 
extreme climate-related exposures the same way that adults do [25]. A warming climate will produce more conflict and violence, which will especially harm children [27].

\subsection{The Various Dimensions of the Anthropocene Dilemmas}

Not all earth scientists agree on how to define the concept of the Anthropocene, and as science is only one point of departure, other fields of thinking have their own definitions. The Anthropocene has become an interdisciplinary concept and there are simultaneously multiple dichotomies of the Anthropocene both within science and beyond, according to Autin [19]. In addition to science dichotomies, she distinguishes between philosophical, political and artistic dichotomies. Through the different dichotomies, people reinforce various views of human interaction with the earth and its consequences, as well as solutions. In the social sciences, the Anthropocene means a break that entails either an environmental awakening or the end of modern society [19]. The future of humanity may either be bright or so extremely catastrophic that it leads to the end of modern society. A positive future may depend on how willing humans are to learn, and modify their ways of dealing with the Earth. In this modification effort, there might be a need for many views and methods.

However, many people see a chance to fix the situation by the use of advanced technology (e.g., geoengineering). Therefore, many proposals have been made on how technically to solve the climate crises, but many researchers and politicians have met these proposals with criticism [28-30]. McLaren [31] warns of the tendency to see the Earth as something to repair, as if the problem would be merely a physical Earth problem, and not an ethical one [32]. Although technology might contribute to solving the global climate crisis to some extent, much larger changes in the human way of life will be necessary. According to Hamilton [11], humankind faces a fatal decision: to continue conquering the Earth by technology or to become humbler and retreat. However, it will be a challenge to prepare the children of today to handle these unpredictable situations and still have a good life. Without doubt, the role of education for the youngest children will be tricky.

"This bizarre situation, in which we have become potent enough to change the course of the Earth yet seem unable to regulate ourselves, contradicts every modern belief about the kind of creature the human being is." [11] vii

At present, humans need a lot of strength in order to make the earth truly viable again. It is certain that humans will need knowledge [11], but, according to Wolff [33] and Stoknes [34] knowledge alone will not automatically lead to changed actions. The will to act is guided by many conflicting desires, for example, a strong desire to obey social dictates, i.e., to avoid attention and conform [33]. Therefore, collective acts towards joint aims are more efficient. As Stoknes [35] frames it:

"The necessary technologies to achieve a low-emission society are already available today. But large-scale systemic changes only come about when enough minds have changed. That means climate change isn't an individual, technical or environmental problem. It's a cultural challenge, with solutions at the organizational social level. The strategies to resolve it must therefore also be social. It will not happen within the framework of rational actors acting individually. Societies change when citizens start to act together with others." [35] (p. 92)

The lack of action may also be due to not knowing how, or not having the skills, to act. Action skills involve the ability to make decisions by investigating and participating in critical discussions, making value judgements about different ways to act and accordingly change current patterns of action [36]. In addition, the freedom and the capability of individuals to act can be limited by political and institutional structures [37]. Consequently, the solutions to the Anthropocene dilemmas depend on individuals as well as collectives.

Nevertheless, humans have to learn to stay within certain moral and bio-geophysical thresholds [38]. This is the basis for Folke and his 21 co-authors' call for a new social contract on 
global sustainability. The climate crisis challenges humans' customary ethics and responsibilities [32]. Therefore, there is a need for both a better awareness of the human limits and more ethical considerations on environmental modification and control. Otherwise, one must consider if Homo sapiens is on its way to becoming a dead-end branch in evolution, since humans threaten their own existence by changing the earth system so that it is no longer favourable to them.

Is there still a way out? Hope is presented as something essential [39], but hope as such is no solution. In education, hope as well as various skills and abilities are necessary. The challenges of the Anthropocene definitely also require people with knowledge about the Earth and a thorough understanding of science. Unfortunately, there are limitations to the way societal actors can respond to the management problems in the Anthropocene, since the way the Earth reacts to human activities is often both complex and unpredictable [40]. Therefore, the ways problems were solved earlier, and the ways unsustainability has hitherto been met and resolved, might be outdated. According to Vizeu, Meneghetti and Seifert [41] the concept of sustainable development is paradoxical, since it tries to solve ecological dilemmas by use of a capitalistic ideology. Smythe [42] asks for a new holistic sustainability paradigm, considering both the human spirit and human needs of nature. She is critical of defining sustainable development through the three dimensions of sustainable development (i.e., ecological, economic and social), since lifting the economic as a dimension separates the issue from the ecological dimension [43]. Economics is a part of human interconnectedness, and thus a part of social life [33].

The science of sustainability in the Anthropocene must be grounded in the operations of the physical world, and the management of change has to be grounded in both knowledge about how the Earth functions and understanding of societal structures [40], but also in ethics [32]. Later in the article we will discuss what this future scenario might demand of ECE. However, we can already state that the problems humanity faces today have to be met directly. They cannot wait until today's children have grown up.

\section{Contemporary Trends in Education Policy}

Sustainability is emphasised in educational policy, both on the international level (e.g., UNESCO, OECD) and the national level (curricula and other policy documents), and by both international and national NGOs, profit-making companies and other agents. Less often, these policies and documents mention the challenges of the Anthropocene, although climate change appears to be an emerging topic. However, it is obvious that sustainability aims are often in conflict with other educational aims, not least economic and developmental aims. To give an example of the connection of ECE to policies, we continue by depicting a few contemporary trends in education policy.

\subsection{Children in the Digital Age}

In recent decades, one of the most discussed topics in educational policy, including ECE policy, has been the role and operationalisation of digital tools in education [15,44-46]. Digital tools are widely used or suggested as being important in ECE for a host of issues, such as inclusion and social development, as well as play, reading, inquiry, storytelling, collaboration, speech learning and activities within natural sciences and mathematics [47-54]. Small handheld mobile devices with touchscreens, such as tablets, seem particularly attractive for use by young children $[50,55]$. The increasing popularity of digital tools in ECE can be viewed as, on the one hand, the introduction of efficient tools for learning, whilst on the other hand, developing the digital ability of children. However, the rapid development of digital tools and their uncoordinated accessibility and availability to young children creates many challenges. Therefore, research concerned with these challenges strives to keep up with the rapidly changing technology [44].

The introduction of digital tools into early childhood institutions is not the only consequence of the digital age for ECE. The digital revolution, with its impact on the economy and society, has altered what are viewed as being important skills and competencies in education. Consequently, 21st century skills are an educational response to the influence digital technology has on our society. 


\subsection{1st Century Skills}

The term "21st century skills" is meant to encapsulate the knowledge, skills and dispositions necessary to succeed in a workplace of a more or less unpredictable future [56,57]. However, 21st century skills are not a clearly-defined or even agreed-upon collection of skills, and many different frameworks for 21st century skills exist [58]. They are commonly presented as a collection of skills divided into the three categories of learning, literacy and life:

- Learning skills: critical thinking, creativity, collaboration and communication;

- Literacy skills: information literacy, media literacy and technology literacy;

- Life skills: flexibility, leadership, initiative, productivity and social skills.

In general, 21st century skills represent a shift from education focusing on the attainment of basic knowledge and skills to an emphasis on being able to apply knowledge and skills through reasoning, problem solving and teamwork.

The concept of 21st century skills dates back to the 1980s. At that time, companies, particularly in the US, identified a shift in what they valued in an employee, from skills such as reading, writing and mathematics, to teamwork, problem solving, and interpersonal skills [56]. Consequently, this skill-set has grown out of business-oriented thinking, with economic organisations such as the OECD as the main driving forces behind its development [59]. Therefore, they are a response to the societal and economic changes resulting from globalisation and the borderless world economy. Since the 1990s, these loosely-defined sets of skills have been embraced as an important component of a modern educational system in most of the western world and elsewhere $[57,59,60]$. However, ideas about 21st century skills have recently been accelerated by the explosion of information and communication technology of the Internet age.

Thus, most of the societal changes which 21st century skills are a response to arise from the fact that technology is boosting competitive aspects of the market economy [61]. Consequently, 21st century skills will help a future workforce in accelerating all aspects of professional life in order to keep afloat in an increasingly digital and globalised competitive arena.

21st century skills are also increasingly mentioned in relation to ECE [62-65]. Commercial training on this topic for early childhood educators occurs in many countries. Early childhood approaches to 21st century skills are usually framed around playful learning, with adults guiding the children as well as providing relevant environments both within the premises of the early childhood institutions and elsewhere [64]. Strategies proposed for attaining 21st century skills advocate approaches that are child-centred and play-based, and have a "whole child" focus with an emphasis on cooperative learning and blended approaches [64].

The general aim of 21st century skills is that learners, being well versed in learning-, literary- and life-skills, will be able to identify, engage and solve a host of professional and personal challenges in the workplace of the future. Yet, although 21st century skills are undoubtedly important qualities for a modern human being, they are not specifically targeted at current challenges of sustainability and the Anthropocene.

However, Bourn [66] claims that there are similarities between 21st century skills and sustainability skills. He also argues that there is too little dialogue between sustainability, the global academic and practitioner groupings. Bourn sees such a dialogue as crucial in promoting change on a global level. Beside skills for work and skills for engaging with a globalised world, he lists understanding what globalisation means, ability to engage in global challenges (e.g., climate change), as well as skills to respect other cultures and critically reflect on one's own value base as important global skills for 21st century professions $[67,68]$.

\subsection{Key Competencies}

A set of educational qualities that is broader than 21st century skills is the concept of key competencies. These key competencies are presented as being "necessary for individuals to lead 
an overall successful life, and for society to solve present and future challenges" [69]. The actual individual and societal needs these competencies are thought to satisfy vary somewhat between different suggested sets of competencies. Yet, at their core, they are meant to solve the challenges of a globalised and ever-changing world. These challenges are continuously accelerated by technological development, much the same as 21st century skills.

Several collections of key competencies important for sustainability education exist, and they share the common goal of qualifying students to become sustainability citizens ([70], chapter 2). For example, in the recent UNESCO treatment of Education for Sustainable Development key competencies [71], the following eight key competencies were suggested as important for sustainability education: systems thinking competency, anticipatory competency, normative competency, strategic competency, collaboration competency, critical thinking competency, self-awareness competency, integrated problem-solving competency. Of these competencies, collaboration and critical thinking competencies are especially included in 21st century skills.

The concept of key competence is widely used when discussing primary education, e.g., the OECD has worked on developing general key competencies partly as background material for PISA [69] as well as teacher education, but they are rarely mentioned in the ECE context. Therefore, we have not discussed them further.

\section{Sustainability and the Challenge of the Anthropocene in ECE}

Research on how to address sustainability in education started in the 1990s [33] and has grown ever since. Sustainability education research in early childhood, on the other hand, has been rare until recently. In 2009, Davis [72] called this scarcity a "research hole" in the field. In her review, she found few studies focusing on children's relationship with nature, even fewer dealing with how children understand environmental topics, and nearly no research on children as change agents. In later reviews, both Hedefalk, Almquist and Östman [36] and Somerville and Williams [73], showed there had been a remarkable increase in research in this field. The focus on sustainability education has also gradually changed. Hedefalk et al. [36] distinguished a change from only teaching children facts about the environment and sustainability issues to also promoting children's agency for change. It is obvious that education has had to change, since the reality that shapes young children's development is also rapidly changing, both locally and globally.

In our review of the research literature on sustainability education, we realised that the terminology varies. Different terms are used, often interchangeably, such as sustainability education, education for sustainable development (ESD) and education for sustainability (EfS) (for a discussion on the use of the different terms, see Wolff [74]). In this paper we have chosen to use the term sustainability education as a general term.

\subsection{Research Areas in Early Childhood Sustainability Education Research}

In the research literature on early childhood (EC) sustainability education, two three-part definitions are used to define sustainability education [36]. Firstly, sustainability education is defined as a threefold approach to education based on three interrelated elements-education about, in and for the environment-also commonly used in environmental education [75]. These three elements emphasise knowledge about the environment, direct experiences in the environment, and personal concern for and action on behalf of the environment. The preposition 'about' draws attention to cognitive aspects of education, such as skills, knowledge and understanding; 'in' recognises the education taking place outside, in authentic surroundings; and 'for' is aimed at purposefully developing attitudes and environmentally friendly or sustainable behaviour [76]. However, the proposition for has met much critique, and been blamed for enhancing the focus on purposeful behaviour change [77].

Secondly, sustainability education has been defined according to the three dimensions of sustainable development in the Earth Summit [78]: ecologic, cultural/social and economic. These three dimensions have been stressed as being important educational goals [79], but they have also 
met a lot of criticism. According to Sauvé [43], considering the economic sphere as its own dimension, and not relating it to the social, is actually a sign that economic interests have come to dominate our current world. Researchers have also added new sustainable development dimensions, like ethics, aesthetics [80], and international justice [81]. According to Kemp, ethics for sustainability relies on care for other persons as well as all other living creatures and their right to live. A more recent model is the doughnut model, in which the ecological dimension is defined as the biophysical boundaries [82] for human opportunities to create a safe and just operating space for human existence within [83]. In this view, the three traditional components of sustainability thinking are not considered to be equal components, but are organised inside the biophysical boundaries, defining the environmental limits within which humanity can use socioeconomic tools and mechanisms to create sustainable societies.

In their review of research in the period between 1996 and 2013, Hedefalk et al. [36] identified two major research areas of sustainability in ECE. The first and the largest group of articles reported on how sustainability education can be implemented in educational practice, both the potential of implementation and how it has been implemented (79 articles), and the second group of articles focused on how teachers understand sustainability education (eight articles). Somerville and Williams' [73], had a somewhat different focus in their review of ECE sustainability research from the year 2009 to 2013. In the 40 research articles they found, they identified three major categories based on the nature of theoretical orientations. They named these categories (1) Connection to nature, (2) Children's rights and (3) Posthuman frameworks.

Bascopé, Perasso and Reiss [84] reviewed 30 articles published between 2003 and 2019. They found three 'main cornerstones' on which to base ECE teachers' professional development. They called these cornerstones (1) The scientific action-integrative scope, (2) The community-based cornerstone, and (3) The value-oriented focus. The first cornerstone emphasises agency, through which children develop scientific competence by active involvement in sustainability processes. The second cornerstone is about learning from and about, and acting upon and with, the community. The last cornerstone highlights practices through which children and adults can jointly develop values in cooperative activities. The Bascopé et al. proposal has a strong connection to science- and art-based inquiries, and calls attention to outdoor education as well as problem-based learning.

In our unsystematic review of a great number of articles on the topic of early childhood sustainability education, we have distinguished four ideas on what this education should focus on, and named them: (1) outdoor play and learning, (2) the competent child and agency, (3) practice architecture and (4) posthumanistic approaches. Below, the text has been arranged according to these four main ideas. However, it is important to note that, in addition to these, there are several other issues and trends that are relevant in early childhood education and policy.

We also want to emphasise that most of the research literature on the topic of sustainability in ECE is from wealthy, industrialised Western countries. As Siraj-Blatchford and Pramling Samuelsson [37] state, sustainable development in many countries concerns more immediate survival issues (such as water and hygiene initiatives) than those addressed in wealthier nations. In addition, Inoue [85] addresses the need to consider the diverse cultural contexts into which sustainability education should fit. She stresses that each nation's education system is informed by its own culture and this must be acknowledged when sustainability education is discussed in international forums. Thus, educational methods should not be adopted uncritically from western cultures into non-western cultures, but the practices should be based on each nation's own cultural contexts [85].

\subsubsection{Outdoor Play and Learning}

In the preface of the book Ecological literacy: Educating our children for a sustainable world [86], Fritjof Capra writes:

"Education for sustainable living fosters both an intellectual understanding of ecology and emotional bonds with nature that make it more likely that our children will grow into responsible citizens who truly care about sustaining life." [86] (xv) 
Play and exploration in natural environments (including wild spaces, urban green spaces and gardens) are considered by many researchers to be an important means for fostering both early understanding of ecology and emotional bonds to nature [87-91]. This view is based on studies that illustrate how children's play in nature provides them with opportunities to become familiar with the natural world through direct experiences and thus enables them to build personal and meaningful relationships with nature [87-89].

Several earlier studies also indicated that positive nature experiences during childhood promote positive attitudes towards nature and nature conservation [92-94]. Adults as role models communicating their interest, knowledge and appreciation of nature, are similarly important [92,93]. These studies have investigated the sources of people's environmental concern and action. A study based on data from nine countries and five continents, including more than 1200 participants, shows that direct experiences of the natural world was the most common factor environmental educators specified as the cause of their interest in and concern for the environment [93]. These results emphasise the importance of providing all children with regular opportunities for play and exploration in natural environments and both Barratt, Barratt-Hackling and Black [87], as well as Beery and Jørgensen [88], express specific concerns regarding today's children's reduced opportunities for direct contact with nature.

Through their studies of adult memories of childhood nature experiences, as well as direct observation of children in nature, Beery and Jørgensen [88] argue for the importance of childhood nature experiences as a point of departure for the development of ecological ideas and embodied environmental understanding. They stress the importance of children's direct encounters with the diversity in nature experienced through sensory rich exploration and self-directed play, which enables children to make connections with nature through their own agency. This contributes to making ecology and biodiversity personally relevant, meaningful and easier to comprehend [95,96]. Giving children opportunities for self-willed exploration and interaction with other species and natural items makes them active participants in their own learning, and enables them to use their experiences and understanding to take action meaningful to their lives [88].

Also, Chawla and Rivkin [89] argue that informal play in nature provides children with a sense of competence to influence the environment. In addition, they stress the importance of adults in encouraging children's appreciation for nature and refer to the role adults play in children's learning through the process of joint attention and social referencing. Besides being role models in showing respect for nature, adults are important in showing children how to express care through actions. Chawla and Rivkin [89] argue that exploring nature together, sharing emotions and paying attention to living organisms and their way of life, develops the perspective-taking which is important for developing sympathy for other living things. Skarstein and Skarstein [91] also point out the role of adults in providing children with opportunities to learn about local nature by sharing their knowledge of common plants and animals encountered while jointly exploring nature. In their study, they discuss how knowledge of local nature is an important factor in developing a desire for environmental protection.

In addition to children's self-directed play in nature, Barratt et al. [87] also emphasise other nature-based experiences, such as growing plants and overnight camping, as important elements in early childhood sustainability education. Such experiences provide children with other kinds of opportunities to modify the environment and develop understanding, skills and values. Spending time in natural environments regularly and observing changes over time may help children to understand life cycles, as well as the idea of living sustainably-that is, to depend on what is around oneself, whilst also sustaining it for the future [87].

\subsubsection{The Competent Child and Agency}

The competent child has been a phenomenon both in the educational discourses in the Nordic countries and in international policy since the end of the 1980s [97]. Within this framework, the child 
has been regarded as an agent, aware of her or his own situation and, therefore, the child's own meaning-making has been central. Competent children are individuals with their own rights and their own views of the world.

When the UN Convention on the Rights of the Child came into force in 1990, the child received status as a universal being with their own rights to respect. Simultaneously, various nations may have expectations of the child as a responsible and flexible social being [97]. On one hand, the view of the competent and flexible child suited the challenges of a fast-changing global economy [97]. On the other hand, this approach, focusing on the competent child, has significantly influenced sustainability education.

The introduction of the Gothenburg recommendations on education for sustainable development [98] emphasises early childhood as a natural foundation for sustainability education. Since children are capable of learning and developing at an early age, early childhood sustainability education may start a process that continues throughout the whole life (lifelong learning). Davis et al. [98] even call early childhood a key step for all sustainability education, and they underscore that sustainability education should relate to the children's daily life.

"ECEfS [Early childhood education for sustainability] has the potential to foster socio-environmental resilience based on interdependence and critical thinking, setting foundations for lives characterized by self-respect, respect for others, and respect for the environment." [98] (p. 26)

As ECE is a highly-gendered field of work, early childhood is also a potential time to foster understanding about social circumstances like inequality and gender issues [98]. Davies et al. have a strong belief in the power of children. According to them, children are competent, active agents in their own lives. They also believe that children can engage in complex environmental and social issues. Therefore, they argue, children can become active agents in the sustainability process, together with teachers, parents and others.

The child's agency is at the core of an article reporting on large research projects on sustainability, which the World Organisation for Early Childhood Education (OMEP) conducted in several countries during UNESCO's Decade on Education for Sustainable Development 2009-2014 [99]. Children are regarded as actors contributing "to both stability and to change in a continuous interplay with their environment" (p. 350). In these child-centred projects with transformation as a goal, the children are problem solvers and change agents. Many other researchers also ask for changes. Davis and Elliott [100] talk about 'the transformative agenda of education for sustainability' (p. 9). Boyd [101] calls early childhood a 'transformative time' and argues "that early childhood educators should empower children to act as critical agents of change" (p. 227).

Many other recent international policy documents and statements emphasise children's important role as active participants in sustainability activities. The Sustainable Development Goals (SDG) or Agenda 2030 [102], as well as Young Children as a Basis for Sustainable Development [103], stress children as central change agents for a better future.

\subsubsection{Practice Architecture}

Even if Davies et al. [98] have a strong belief in children (see previous paragraphs), they want to see the adults as role models acting with the children in a kind of joint agency. That is, they want to see ECE settings as places that practice sustainability. According to Davies et al., early childhood institutions should strive to live sustainably not only when it comes to consumption, but also when it comes to social practices, to align the doings with the sayings, shaping EC institutions towards aiming at "living in a sustainable culture" (p. 31).

The quest for ECE in which common practical actions correspond to the message that the organisation communicates and the way in which people relate to each other is based on Stephen Kemmis' ideas. In such a 'sustainability architecture', culturally discursive, material-economic and 
social-political choices harmonise [104,105]. It is about personal wisdom, based on what Aristotle calls fronesis, which is applied in practical collaborative action [106] through which one strives to live as one learns. According to this thinking, didactics is a process in which people of different ages are taught how to relate to each other and the outside world through knowledge of different forms and by participating in joint activities [104]. It is a process that supports the development of the individual identity and autonomy as well as the development of collective action. The aim is to achieve a good life for individuals and all of humanity across the planet [105]. There are some similarities between the practice architecture and the whole school approach [107].

\subsubsection{Posthumanistic Approaches}

In contrast to the competent child advocates, Taylor [108] is critical of seeing humans as change agents. According to her, this view is an example on stewardship pedagogies built on outmoded humanist principles, where the learners become environmental stewards. Taylor, who has chosen a posthumanistic approach, does not find these change agent educational approaches to be radical enough to generate the change that is needed in the education of children in the Anthropocene. According to her, the challenges of this era need a reframing of the human species as one among other species: "The challenges of growing up in an increasingly complex, mixed-up, boundary blurring, heterogeneous, interdependent and ethically confronting world" demands something other than an approach focusing on individuals, according to Taylor, Pacinini-Ketchabaw and Blaise [109] (p. 81). Haraway [110] uses the words making kin, implying that practices for non-hierarchically recognizing and caring about kin should be invented. Her use of the word kin is not limited to humans, and she is searching for multi-species environmental justice. Making kin is about a reorientation and a disassembly of the boundaries between the human and nonhuman worlds that include other biological species, abiotic factors and non-living things like technology $[108,110,111]$.

"[The] common world's response to the Anthropocene is quite simply to keep working at ways of becoming more worldly through focusing upon our entangled relations with the more-than-human world." [108] (p. 1458)

Haraway [112] even prefers to see the Anthropocene more as a boundary event, marking severe discontinuities, and uses the name Chthulucene for our current epoch—an epoch in which rich multispecies assemblages might be possible.

There are many parallel and partly overlapping posthumanistic views. They are all part of a philosophical turn aiming towards a new ontology in which the human has lost its role as a node [113]. When searching for answers as to what ECE in the Anthropocene could be, we noticed that many authors referring to the concept of the Anthropocene in early childhood research seemed more or less to align with posthumanistic views [108,113-115]. These views are critical of the scientific way of encountering the natural world, in which the advocates believe that nature easily becomes an object. This tendency is seen as being based on an ontological and epistemological nature-culture division [108]. Instead, the posthumanists request a relational, embodied and affective immersion with other lifeforms [116] and empathy towards the self and others [115], the so called more-than-humans. Posthumanistic thinking has been inspired by the ideas of Karen Barad, among others. She uses the concept intra-activity, and argues for a flat ontology without hierarchies between humans and other creatures and things $[117,118]$.

“'We' are not outside observers of the world. Nor are we simply located at particular places in the world; rather, we are part of the world in its ongoing intra-activity." [117] (p. 30)

Educational philosophy is strongly engaged with how education might respond to the challenges of the Anthropocene [119]. Actually, our literature review has shown us that there are no other educational voices that discuss this topic as much as those belonging to philosophy, and especially the ontological approach called posthumanism. Notably, Britton, Haverkos, Kutner, Shume and 
Tippins [120] are sceptical of the posthumanistic approach in their review of the book Reimagining Sustainability in Precarious Time (edited by Malone, Troung and Gray). According to the reviewers, the 24 authors of the book do not manage to overcome the obstacles and binaries they try to avoid. This is a problem we will return to in the discussion below.

\section{Discussion}

We will now discuss the findings from our review of literature on the Anthropocene, contemporary policy documents on education and EC sustainability education research, and view them in light of classic philosophy. Our reviewing method has not been systematic, but it was thorough. While aware of the different circumstances in different parts of the world, our study mainly addressed western society, the society we are most familiar with, and it might therefore sound inadequate in a global sense. However, according to global ideals, it is the responsibility of those living in wealth to enable and empower those suffering (Leaving No One Behind, UN 2030 Agenda for Sustainable Development). This implies taking action to end poverty, limiting inequalities and discrimination, and showing a willingness to accept responsibility. Nevertheless, challenging inequality and unsustainability starts with recognising that things can be changed, i.e., seeing things differently.

\subsection{The Role of Education in the Anthropocene}

Regardless of if one agrees with the concept of the Anthropocene or not, the research on this topic clearly shows that the modern human way of living affects the earth in ways that already have had severe consequences. If nothing is done to stop the undesired processes, the damage will increase rapidly. One way of changing modern lifestyles has always been through education [33]. However, human-induced climate change and the more overarching idea of the Anthropocene are extremely complex and unpredictable issues, so how to educate about this is not self-evident.

The adults and children of today need a lot of knowledge and a range of skills to handle the future. There is not one way to go, but many, and education needs to consider all the options. From the beginning of the 1990s there has been a focus on ECE in international education policies [97]. Young children often turn up in the middle of the intersection (and even battlefields) between social change, research and political reform programs. In the role of newcomers in the world, children are considered potential agents of change, whether they are regarded as natural, mythical, rational or competent [97]. The child has, for example, been seen as a flexible and skilful entrepreneur with future participatory potentials [97]. According to Castañeda [121], the child has often been seen as 'not yet', but with a 'capacity to become'. The child is then not only 'in the making', but also changeable. In an era of crises, the children therefore easily become those who have to fulfil the older generation's utopian dreams about a better world.

The problem is that ambitions regarding the next generation vary considerably. From our reading of current policy documents on education, it is our impression that, within the ECE sector, one of the more important challenges of the 21st century relates to how the digital age is transforming the global economy and the qualities needed in workers to succeed in this economy. Consequently, attempts to attune ECE to 21st century challenges largely aim at introducing digital tools into ECE. It is our clear conviction that this emphasis needs to be seriously re-evaluated and shifted towards the challenges of the Anthropocene, since the underlying goals are basically different. So, although the potential benefits of so-called 21st century skills can be many, it is worth questioning certain aspects of their origins and of goals with close ties to marked-oriented thinking. It appears that 21st century skill-sets have grown out of a worldview somewhat distant from the educational ideal of Bildung [122] and a more ideal purpose of education as a way to create whole humans empowered to live good lives [123]. Educating children to become a workforce adapted to whatever the work-environment dictates, drives humans into ever more rapid cycles of change. This is more a way to treat symptoms than an attempt to find solutions to the challenges of an increasingly hectic and unpredictable work environment that forces humans to shift and change faster than ever before. In many ways, this mirrors the Red Queen 
scene from Lewis Carroll's novel Through the Looking Glass, when the queen says to Alice: "it takes all the running you can do, to keep in the same place" [124]. We're running faster and faster, but for what reason?

Many even regard 21st century skills as a contribution to the depletion of resources and unmanageable pollution challenges by scaffolding consumerism and the idea of limitless economic growth. In the words of David Orr, education along these lines of thinking can "equip people to become more effective vandals of the Earth" [125] (p. 5). In other words, 21st century skills are composed of skills and competencies that are useful in and by themselves but, at a system level, they may become problematic in the manner in which they maintain and potentially accelerate the core issues of the Anthropocene. It is thus important not only to look at which skills might be important in the future, but to discuss the value base of education needed in the Anthropocene.

\subsection{ECE and the Anthropocene}

In this article, we have presented four main approaches, suggested by EC research, to sustainability education and how to meet the challenges of the Anthropocene. We have named these approaches: outdoor play and learning, competent child and agency, practice architecture and posthumanistic approaches. It is obvious that there are similarities between these approaches, e.g., between the competent child and agency and practice architecture. Likewise, there are some shared features between the outdoor play and learning approach and the posthumanistic approaches, such as a focus on nature and relationships between humans and other parts of nature. Yet, the outdoor approach is practical and posthumanism an ontology, and the differences are very obvious on many levels. The theory base varies completely between the competent child and agency ideas that lean on constructivism compared to practice architecture based on Aristotle's virtue ethics. As mentioned before, the research literature also provides other suggestions for approaches other than those mentioned here. For example, Bascopé et al. [84] suggest a transdisciplinary ECE that combines indigenous knowledge, intergenerational exchange, scientific knowledge and traditional lifestyles with local practices.

In our opinion, both the outdoor play and learning approach and the competent child and agency approach are applicable in education in the Anthropocene-not necessarily as alternatives to each other, but rather complementing each other and potentially also other approaches. Children need to become familiar with nature in authentic environments, so that they are able to build emotional bonds with nature. They also need to feel that they are competent, active agents in their own lives. Childhood is first and foremost the time to train good living in a safe environment. Practice architecture is a way to arrange such an environment and such an ethos. Bourn [68] underscores the whole school approach as a place where the topic global learning has been included as an ethos. This ethos is then obvious in lessons, assemblies, extra-curricular activities and methods. Similarly, learning in the Anthropocene requires a holistic approach and it needs to take place both outdoors and indoors, where the children can participate in a meaningful life here and now.

Perhaps a significant and underdeveloped transformative role of ECE is to develop new practice architectures which allow children to explore narratives of good lives outside the dominating tale of consumerism in today's society. That is, in the terminology presented by Stephen Sterling [126], humans need to shift their perspectives on learning from doing things better and doing better things, to learning to see things differently. As Arne Næss [127] stressed in his deep ecology movement, an ideological change is necessary, one in which appreciating life quality becomes more important than adhering to an increasingly higher standard of living. He also emphasised the importance of an understanding of the mutual dependence of all living organisms and systems, and how the wellbeing of one part of the system is dependent on the wellbeing of the whole. An ECE focus on teaching children to see things differently would make ECE truly transformative.

Lately, many researchers have mentioned posthumanism as a kind of solution to meet the challenges of the Anthropocene in ECE. Yet, this approach is not problem free. As Taylor and Pacini-Ketchabaw [128] (p. 526) themselves write, decentring the human "is no easy task and there 
have been limits to our work". It is hard not to position small children as central actors and neglect an ethics based on a human-centric care for the other. It seems difficult to take care of and educate small children if they are not allowed to have a centric position. However, examining and experimenting with new ways of thinking and new philosophical approaches, such as posthumanism, is definitely important. In a time when urgent actions are required, it is a fact that experiments take time and the time might be running out.

De Geus [129] believes that sustainability can be reached through a utopian-inspired ecological 'art of living'. This requires very complex individual and social learning processes that focus on a combination of individual freedom and diverse lifestyles with social-ecological and moral responsibilities. Critical ecotopias focus on a fair distribution of goods and a plural view of the good life. Too utopian ideas, like some of the posthuman approaches, might be risky, since they might be misunderstood as blueprints, similar to what happened to Rousseau's Émile in the 18th century [33].

There have been few studies about education in relation to the Anthropocene, and although there has been remarkable progress in early childhood sustainability education research during the last few years, this field is still relatively new and in need of more research that underpins practice [84]. As Hedefalk et al. [36] point out, there is a need for more empirical research as well as more research on children's learning processes concerning sustainability education.

\subsection{Education and Values}

Sustainability education could be one of the pillars on which to build education in the Anthropocene. Twenty-first century skills, especially Bourn's enlarged version [66-68], could be another. Yet, the way 21st skills are implemented is dependent on the values of educational practice. If the values of the educational framework are not sustainable, then the skills will open a direction other than it would if the framework was sustainable. However, none of these, including the posthumanistic approaches, seem to provide appropriate support to the understanding of Earth's systems [10].

Living as a human being in the Anthropocene quandary means understanding and managing Earth systems, and understanding what it means to be a social human being and thus part of both these interconnected systems, the social and the natural world, now and in an unpredictable future $[33,90]$. The science of sustainability needs to be based on knowledge about the physical world [90], but also on social interactions, and to grasp the whole picture humans also need to understand themselves [33]. The mission of all education is to strive towards all these dimensions. Humans need to understand nature, social interactions and themselves as persons, and it is not merely about understanding, but also values, willingness and the ability to act [33].

Ritchie [115] stresses that educators have an ethical responsibility towards children, their families and the whole community they serve. This is fundamental in early childhood education. However, this responsibility does not exclude their duties and respect for the entire planet. When it comes to young children, the educators' endeavours regarding all these parts need to be balanced; and this balance has to rise from deep ethical discussions among the educators and diverse collaborative parts, not least the parents. Changed habits require a total reconstruction of the learning frameworks. Regardless of which strong goals direct ECE, there is always a risk that the children will become the means of the purpose of others, not as ends in themselves [130]. According to Immanuel Kant, humans have to treat themselves and others as rational beings-not as means, but as ends in themselves. In one version of the categorical imperative, Kant formulates it like this: "A human being, however, is not a thing, and hence not something that can be used merely as a means but must in all his actions always be regarded as an end" [130] (p. 38). With this in mind, it is of utmost importance to consider what kind of ECE will be ethically acceptable in the long run.

Irrespective of the goals, the child must be the main focus of ECE. One also needs to consider if it is the children's role, as future adults, to be the ones who contribute to the big changes. Or should it be the role of today's adults to lead the change and prepare children to live in a changed world-either a sustainable world or, if the adults do not succeed, a world of ever accelerating environmental crises? 
In any case, it is important to educate the children to adapt to changes by promoting features like creativity, critical thinking, collaboration and responsibility. It is also essential to start working for change directly and involve the children in the practice of a meaningful and positive lifestyle. In such a practice, care for humans and other living things, as well as the wellbeing of the entire Earth, is an immanent ethos.

Nevertheless, child involvement does not mean that children must be considered responsible. The adults are still the source of authority, with the right and duty to guide and support the child and to make wise decisions, while respecting children's rights [131]. Therefore, children should not have to decide on matters with consequences they are unable to discern [131]. It is important to consider this, regardless of whether the arena is ECE or the home.

It is also worthwhile considering that, even if children are easily transformed, they should not be misused in the interest of adults. Children should not become "an object of adult knowledge and realization" [121] (p. 167). Their rights must not be threatened, and children should not carry the burden of all humanity [85]. In preschools, child-initiated activities and shared activities between children and teachers are important, and can be developed jointly. However, these activities need to be attuned to children's level of understanding and ability to progress. Early childhood is not the time to try to save the entire planet. It is only the beginning. The youngest children need to grow in comfortable environments without obvious threats and frightening news.

\section{Conclusions}

"[C]hanging the habits of a global society is not a trivial task in itself" [19] (p. 220). However, the Anthropocene concept offers opportunities to educate and introduce new ways of thinking [19]. We have employed the concept of the Anthropocene here to trigger a crucial educational discussion on a central, epochal key issue. The aim of this study was to find out what the mission of early childhood education might be in the age of the Anthropocene. We approached this aim through three research questions: (1) What knowledge will prepare young children to live in the epoch of Anthropocene? (2) Which skills will prepare young children to live in the Anthropocene? and (3) What should the value base of ECE be in the Anthropocene? These three questions are intermingled, and it is difficult to answer them separately. What we tried to do in this study was combine the ECE field with other fields to paint a larger picture of the challenges of sustainability education. The Anthropocene requires many kinds of knowledge and skills, and learning these begins through play and experiences in early childhood. Education in the Anthropocene needs to be based on knowledge as well as abilities that relate to both the social and the natural world. However, it is not enough to examine knowledge or skills separately. It is essential to discuss the value base the knowledge and skills are related to, especially since the Anthropocene challenges are strongly value-dependent.

All the approaches to EC sustainability education, which we have presented here, offer important views. We therefore call for more dialogue among researchers on how different approaches and views may interact with and complement each other. There are many perspectives on what ECE in the Anthropocene entails that need to be studied more thoroughly than we have done in this article. This includes perspectives such as the limits of children's agency, the child's role in families and communities, the value dichotomies in children's lives, and how these affect sustainability education in ECE.

However, given the urgency and gravity of the challenges of the Anthropocene, education alone is not enough to bring about sufficient change. It is our conviction that, at this moment, the world's environmental challenges need great and fast transformative actions and the challenges have to be met directly. Responsibility for action lies in the hands of the adults, while the children are the ones who will invent, tell and live the narratives of tomorrow. The mission of ECE in the Anthropocene should therefore be to allow and enable children to imagine and practice a good, safe and sustainable future in environments steered by a strong, vital and life-upholding ethos. 
Author Contributions: All authors have read and agree to the published version of the manuscript. Conceptualisation, L.-A.W., T.H.S. and F.S.; methodology, L.-A.W., T.H.S. and F.S.; investigation, L.-A.W., T.H.S. and F.S.; resources, L.-A.W., T.H.S. and F.S.; writing-original draft preparation, L.-A.W., T.H.S. and F.S.; writing-review and editing, L.-A.W., T.H.S. and F.S.

Funding: The Finnish part of this research received funding through the project Sustainable Stories in Early Childhood education (SUSTE), financed by The Swedish Cultural Foundation in Finland. The stay of TS and FS in Finland during the conception and writing of this paper was made possible by funding from the Faculty of Arts and Humanities at the University of Stavanger, Norway. The research programme Interfaces at the University of Stavanger also contributed with funding.

Conflicts of Interest: The authors declare no conflict of interest.

\section{References}

1. Meadows, D.H.; Meadows, D.L.; Randers, J.; Behrens, W.W. The Limits to Growth; Penguin Group: New York, NY, USA, 1972; p. 27.

2. Rieckmann, M. Education for Sustainable Development Goals: Learning Objectives; UNESCO Publishing: Paris, France, 2017.

3. Rodríguez-Labajos, B.; Yánez, I.; Bond, P.; Greyl, L.; Munguti, S.; Ojo, G.U.; Overbeek, W. Not So Natural an Alliance? Degrowth and Environmental Justice Movements in the Global South. Ecol. Econ. 2019, 157, 175-184. [CrossRef]

4. Robra, B.; Heikkurinen, P. Degrowth and the Sustainable Development Goals. 2019. Available online: https://link.springer.com/referenceworkentry/10.1007\%2F978-3-319-71058-7_37-1 (accessed on 8 January 2020).

5. Uljens, M.; Wolff, L.-A.; Frontini, S. Finland: NPM resistance or towards European neo-welfarism in education. In New Public Management and the Reform of Education; Routledge: London, UK, 2016; pp. 57-70.

6. Opetushallitus (Ed.) Esiopetuksen Opetussuunnitelman Perusteet 2014; Opetushallitus: Helsinki, Finland, 2014.

7. Opetushallitus (Ed.) Varhaiskasvatussuunnitelman Perusteet 2018; Opetushallitus: Helsinki, Finland, 2018.

8. Norwegian Directorate for Education and Training. Framework Plan for Kindergartens_Contents and Tasks; Norwegian Directorate for Education and Training: UDIR, Oslo, 2017.

9. Pihkala, P. Eco-anxiety, tragedy, and hope: Psychological and spiritual dimensions of climate change. Zygon 2018, 53, 545-569. [CrossRef]

10. Preiser, R.; Pereira, L.M.; Biggs, R.O. Navigating alternative framings of human-environment interactions: Variations on the theme of 'Finding Nemo'. Anthropocene 2017, 20, 83-87. [CrossRef]

11. Hamilton, C. Defiant Earth: The Fate of Humans in the Anthropocene; Polity Press: Camrbidge, UK, 2017.

12. Rawson, J.; Whitmore, J. The Handbook: Surviving and Living with Climate Change; Transit Lounge: Melbourne, Australia, 2015.

13. Trilling, B.; Fadel, C. 21st Century Skills: Learning for Life in Our Times; John Wiley \& Sons: San Fransisco, CA, USA, 2009.

14. Vaikutytė-Paškauskè, J.; Vaičiukynaitè, J.; Pocius, D. Research for CULT Committee-Digital Skills in the 21st century; European Parliament, Policy Department for Structural and Cohesion Policies: Brussels, Belgium, 2018.

15. Schleicher, A. Helping Our Youngest to Learn and Grow: Policies for Early Learning. International Summit on the Teaching Profession; OECD Publishing: Paris, France, 2019.

16. Graafland, J.H. New Technologies and 21st Century Children: Recent Trends and Outcomes; OECD Publishing: Paris, France, 2018.

17. Klafki, W. Erziehung - Humanität - Demokratie: Erziehungswissenschaft und Schule an der Wende zum 21. Jahrhundert. Neun Vorträge [Education - humanity - democracy: Educational theory and school at the 21. Millennium shift. Nine lectures]. 1998. Available online: http:/archiv.ub.uni-marburg.de/sonst/1998/0003/ welcome.html (accessed on 8 January 2020).

18. Crutzen, P.J. The "anthropocene". In Earth System Science in the Anthropocene; Springer: Berlin/Heidelbarg, Germany, 2006; pp. 13-18.

19. Autin, W.J. Multiple dichotomies of the Anthropocene. Anthr. Rev. 2016, 3, 218-230. [CrossRef]

20. Sörlin, S. Antropocen: En Essä om Människans Tidsålder; Weyler förlag: Stockholm, Sweden, 2017. 
21. Waters, C.N.; Zalasiewicz, J.; Summerhayes, C.; Barnosky, A.D.; Poirier, C.; Gałuszka, A.; Cearreta, A.; Edgeworth, M.; Ellis, E.C.; Ellis, M. The Anthropocene is functionally and stratigraphically distinct from the Holocene. Science 2016, 351, aad2622. [CrossRef] [PubMed]

22. Steffen, W.; Sanderson, R.A.; Tyson, P.D.; Jäger, J.; Matson, P.A.; Moore, B., III; Oldfield, F.; Richardson, K.; Schellnhuber, H.-J.; Turner, B.L. Global Change and the Earth System: A Planet Under Pressure; Springer Science \& Business Media: Berlin/Heidelberg, Germany, 2006.

23. Ceballos, G.; Ehrlich, P.R.; Dirzo, R. Biological annihilation via the ongoing sixth mass extinction signaled by vertebrate population losses and declines. Proc. Natl. Acad. Sci. USA 2017, 114, E6089-E6096. [CrossRef] [PubMed]

24. Lewis, S.; Maslin, M. Human Planet: How We Created the Anthropocene; Yale University Press: London, UK, 2018.

25. Tillett, T. Climate change and children's health: Protecting and preparing our youngest. Environ. Health Perspect. 2011, 119, 132. [CrossRef]

26. Council on Environmental Health. Global climate change and children's health. Pediatrics 2015, 136, 992-997. [CrossRef]

27. Akresh, R. Climate change, conflict, and children. Future Child. 2016, 26, 51-71. [CrossRef]

28. Lawrence, M.G.; Schäfer, S.; Muri, H.; Scott, V.; Oschlies, A.; Vaughan, N.E.; Boucher, O.; Schmidt, H.; Haywood, J.; Scheffran, J. Evaluating climate geoengineering proposals in the context of the Paris Agreement temperature goals. Nat. Commun. 2018, 9, 3734. [CrossRef]

29. Tollefson, J. First sun-dimming experiment will test a way to cool Earth. Nature 2018, 563, 613-615. [CrossRef] [PubMed]

30. Tollefson, J. Geoengineering debate shifts to UN environment assembly. Nature 2019, 567, 156. [CrossRef] [PubMed]

31. McLaren, D.P. In a broken world: Towards an ethics of repair in the Anthropocene. Anthr. Rev. 2018, 5, 136-154. [CrossRef]

32. Minteer, B.A. Geoengineering and ecological ethics in the Anthropocene. BioScience 2012, 62, 857-858.

33. Wolff, L.-A. Nature and Sustainability: An Educational Study with Rousseau and Foucault; Lambert Academic: Saarbrücken, Germany, 2011.

34. Stoknes, P.E. Rethinking climate communications and the "psychological climate paradox". Energy Res. Soc. Sci. 2014, 1, 161-170. [CrossRef]

35. Stoknes, P.E. What We Think About When We Try Not to Think About Global Warming: Toward a New Psychology of Climate Action; Chelsea Green Publishing: White River Junction, VT, USA, 2015.

36. Hedefalk, M.; Almqvist, J.; Östman, L. Education for sustainable development in early childhood education: A review of the research literature. Environ. Educ. Res. 2015, 21, 975-990. [CrossRef]

37. Siraj-Blatchford, J.; Pramling-Samuelsson, I. Education for sustainable development in early childhood care and education: An introduction. In International Research on Education for Sustainable Development in Early Childhood; Springer: Berlin/Heidelberg, Germany, 2016; pp. 1-15.

38. Folke, C.; Jansson, Å.; Rockström, J.; Olsson, P.; Carpenter, S.R.; Chapin, F.S.; Crépin, A.-S.; Daily, G.; Danell, K.; Ebbesson, J. Reconnecting to the biosphere. Ambio 2011, 40, 719-738. [CrossRef]

39. Hicks, D. Educating for Hope in Troubled Times: Climate Change and the Transition to a Post-Carbon Future; Institute of Education Press London: London, UK, 2014.

40. Knight, S. Forest school in the United Kingdom. In Routledge International Handbook of Outdoor Studies; Humberstone, B., Prince, H., Henderson, K.A., Eds.; Routledge: Abingdon, UK, 2015; pp. 244-250.

41. Vizeu, F.; Meneghetti, F.K.; Seifert, R.E. Por uma crítica ao conceito de desenvolvimento sustentável. Cadernos Ebape. br 2012, 10, 569-583. [CrossRef]

42. Smythe, K.R. An historian's critique of sustainability. Cult. Unbound: J. Curr. Cult. Res. 2014, 6, $913-929$. [CrossRef]

43. Sauvé, L. Environmental education: Possibilities and constraints. Connect: UNESCO Int. Sci. Technol. Environ. Educ. Newsl. 2002, 27, 1-4.

44. Kucirkova, N.; Rowsell, J.; Falloon, G. The Routledge International Handbook of Learning with Technology in Early Childhood; Routledge: London, UK, 2019.

45. Palaiologou, I. Children under five and digital technologies: Implications for early years pedagogy. Eur. Early Child. Educ. Res. J. 2016, 24, 5-24. [CrossRef] 
46. Scott, F.; Marsh, J. Digital Literacies in Early Childhood. In Oxford Research Encyclopedia of Education; Oxford University Press: Oxford, UK, 2018.

47. Bouck, E.C.; Satsangi, R.; Flanagan, S. Focus on Inclusive Education: Evaluating Apps for Students with Disabilities: Supporting Academic Access and Success: Bradley Witzel, Editor. Child. Educ. 2016, 92, 324-328. [CrossRef]

48. Danby, S.; Fleer, M.; Davidson, C.; Hatzigianni, M. Digital Childhood; Springer: Berlin/Heidelberg, Germany, 2018.

49. Hoel, T.; Tønnessen, E.S. Organizing Shared Digital Reading in Groups: Optimizing the Affordances of Text and Medium. AERA Open 2019, 5. [CrossRef]

50. Kalogiannakis, M.; Ampartzaki, M.; Papadakis, S.; Skaraki, E. Teaching natural science concepts to young children with mobile devices and hands-on activities. A case study. Int. J. Teach. Case Stud. 2018, 9, 171-183. [CrossRef]

51. Maureen, I.Y.; van der Meij, H.; de Jong, T. Supporting literacy and digital literacy development in early childhood education using storytelling activities. Int. J. Early Child. 2018, 50, 371-389. [CrossRef]

52. Otterborn, A.; Schönborn, K.; Hultén, M. Surveying preschool teachers' use of digital tablets: General and technology education related findings. Int. J. Technol. Des. Educ. 2019, 29, 717-737. [CrossRef]

53. Sung, W.; Ahn, J.; Black, J.B. Introducing computational thinking to young learners: Practicing computational perspectives through embodiment in mathematics education. Technol. Knowl. Learn. 2017, 22, 443-463. [CrossRef]

54. Zaranis, N.; Kalogiannakis, M.; Papadakis, S. Using mobile devices for teaching realistic mathematics in kindergarten education. Creat. Educ. 2013, 4,1-10. [CrossRef]

55. Falloon, G. Young students using iPads: App design and content influences on their learning pathways. Comput. Educ. 2013, 68, 505-521. [CrossRef]

56. Care, E.; Griffin, P.; McGaw, B. Assessment and Teaching of 21st Century Skills; Springer: Berlin/Heidelberg, Germany, 2012.

57. Delors, J. Learning: The Treasure Within; UNESCO: Paris, France, 1998.

58. Germaine, R.; Richards, J.; Koeller, M.; Schubert-Irastorza, C. Purposeful Use of 21st Century Skills in Higher Education. J. Res. Innov. Teach. 2016, 9, 19-29.

59. Ananiadou, K.; Claro, M. 21st century skills and competences for new millennium learners in OECD countries; OECD: Paris, France, 2009.

60. Bellanca, J.A. 21st Century Skills: Rethinking How Students Learn; Solution Tree Press: Bloomington, IN, USA, 2010.

61. Forum, W.E. New Vision for Education: Unlocking the Potential of Technology; British Columbia Teachers' Federation: Vancouver, Canada, 2015.

62. Auld, E.; Morris, P. The OECD and IELS: Redefining early childhood education for the 21st century. Policy Futures Educ. 2019, 17, 11-26. [CrossRef]

63. Kennedy, A.S.; Heineke, A. Re-envisioning the role of universities in early childhood teacher education: Community partnerships for 21st-century learning. J. Early Child. Teach. Educ. 2014, 35, 226-243. [CrossRef]

64. Batelle for Kids. 21st Century Learning for Early Childhood-Framework. Available online: http: //static.battelleforkids.org/documents/p21/P21EarlyChildhoodFramework.pdf (accessed on 10 December 2019).

65. Lasser, J.; Fite, K. Universal preschool's promise: Success in early childhood and beyond. Early Child. Educ. J. 2011, 39, 169-173. [CrossRef]

66. Bourn, D. Understanding Global Skills for 21st Century Professions; Springer: Berlin/Heidelberg, Germany, 2018.

67. Bourn, D. The Theory and Practice of Development Education: A Pedagogy for Global Social Justice; Routledge: London, UK, 2014.

68. Bourn, D. Global learning and the school curriculum. Manag. Educ. 2016, 30, 121-125. [CrossRef]

69. Salganik, L.; Rychen, D.; Moser, U.; Konstant, J. Definition and Selection of Competencies: Theoretical and Conceptual Foundations (DeSeCo); Swiss Federal Statistical Office: Neuchâtel, Switzerland, 1999.

70. Leicht, A.; Heiss, J.; Byun, W.J. Issues and Trends in Education for Sustainable Development; UNESCO Publishing: Paris, France, 2018; Volume 5.

71. Rieckmann, M. Learning to transform the world: Key competencies in Education for Sustainable Development. In Issues and Trends in Education for Sustainable Development; UNESCO: Paris, France, 2018; p. 39. 
72. Davis, J. Revealing the research 'hole' of early childhood education for sustainability: A preliminary survey of the literature. Environ. Educ. Res. 2009, 15, 227-241. [CrossRef]

73. Somerville, M.; Williams, C. Sustainability education in early childhood: An updated review of research in the field. Contemp. Issues Early Child. 2015, 16, 102-117. [CrossRef]

74. Wolff, L.-A.; Sjöblom, P.; Hofman-Bergholm, M.; Palmberg, I. High performance education fails in Sustainability?-A reflection on finnish primary teacher education. Educ. Sci. 2017, 7, 32. [CrossRef]

75. Neal, P.; Palmer, J. The handbook of Environmental Education; Routledge: New York, NY, USA, 1994.

76. Scoullos, M.; Malotidi, V. Handbook on methods used in environmental education and education for sustainable development; Mio-ECSDE: Athens, Greece, 2004.

77. Jickling, B.; Spork, H. Education for the environment: A critique. Environ. Educ. Res. 1998, 4, $309-327$. [CrossRef]

78. UNCED. UNCED, 1992. The Earth Summit: The United Nations Conference on Environment and Development (UNCED); United Nations Conference on Environment and Development: London, UK, 1992.

79. Tilbury, D. Emerging issues in education for sustainable development. In Education for sustainable development in Nepal: Views and visions; Bhandari, B.B., Abe, O., Eds.; International Institute for Global Environmental Strategies (IGES): Hayama, Japan, 2003; pp. 29-40.

80. Cantell, H. Tarjolla kestävää kehitystä-mutta miksi ei ympäristökasvatusta? [Sustainable development available: But why not environmental education?]. Available online: https:/link.springer.com/ referenceworkentry/10.1007\%2F978-3-319-71058-7_37-1 (accessed on 8 January 2020).

81. Kemp, P. Väldsmedborgaren: Politisk och Pedagodisk Filosofi för det 21 Århundradet [The Cosmopolitan: Political and Educational Philosophy for the 21th Century]; Daidalos: Göteborg, Sweden, 2005.

82. Rockström, J.; Steffen, W.L.; Noone, K.; Persson, Å.; Chapin, F.S., III; Lambin, E.; Lenton, T.M.; Scheffer, M.; Folke, C.; Schellnhuber, H.J. Planetary boundaries: Exploring the safe operating space for humanity. Ecol. Soc. 2009, 14, 32. [CrossRef]

83. Vince, G.; Raworth, K. Living in the doughnut. Nat. Clim. Chang. 2012, 2, 225-226. [CrossRef]

84. Bascopé, M.; Perasso, P.; Reiss, K. Systematic review of education for sustainable development at an early stage: Cornerstones and pedagogical approaches for teacher professional development. Sustainability 2019, 11, 719. [CrossRef]

85. Inoue, M. Perspectives on early childhood environmental education in Japan: Rethinking for a sustainable society. Framing the text. In Research in Early Childhood Education for Sustainability: International Perspectives and Provocations; Davis, J., Elliott, S., Eds.; Routledge: London, UK, 2014; pp. 79-96.

86. Stone, M.K.; Barlow, Z. Ecological Literacy: Educating our Children for a Sustainable World; Sierra Club Books: San Fransisco, CA, USA, 2005.

87. Barratt, R.; Barratt-Hacking, E.; Black, P. Innovative approaches to early childhood education for sustainability in England: Case studies from the field. In Research in Early Childhood Education for Sustainability: International Perspectives and Provocations; Davis, J., Elliott, S., Eds.; Routledge: London, UK, 2014; pp. 225-247.

88. Beery, T.; Jørgensen, K.A. Children in nature: Sensory engagement and the experience of biodiversity. Environ. Educ. Res. 2018, 24, 13-25. [CrossRef]

89. Chawla, L.; Rivkin, M. Early childhood education for sustainability in the United States of America. In Research in Early Childhood Education for Sustainability: International Perspectives and Provocations; Davis, J., Elliott, S., Eds.; Routledge: London, UK, 2014; pp. 248-265.

90. Knight, J. Anthropocene futures: People, resources and sustainability. Anthr. Rev. 2015, 2, 152-158. [CrossRef]

91. Skarstein, T.H.; Skarstein, F. Curious children and knowledgeable adults-Early childhood student-teachers' species identification skills and their views on the importance of species knowledge. Int. J. Sci. Educ. 2020. [CrossRef]

92. Chawla, L. Childhood experiences associated with care for the natural world: A theoretical framework for empirical results. Child. Youth Environ. 2007, 17, 144-170.

93. Palmer, J.A.; Suggate, J.; Bajd, B.; Ho, R.K.; Ofwono-Orecho, J.; Peries, M.; Robottom, I.; Tsaliki, E.; Staden, C.V. An overview of significant influences and formative experiences on the development of adults' environmental awareness in nine countries. Environ. Educ. Res. 1998, 4, 445-464. [CrossRef]

94. Wells, N.M.; Lekies, K.S. Nature and the life course: Pathways from childhood nature experiences to adult environmentalism. Child. Youth Environ. 2006, 16, 1-24. 
95. Helldén, G.; Helldén, S. Students' early experiences of biodiversity and education for a sustainable future. Nord. Stud. Sci. Educ. 2008, 4, 123-131. [CrossRef]

96. Magntorn, O.; Helldén, G. Student-Teachers' Ability to Read Nature: Reflections on their own learning in ecology. Int. J. Sci. Educ. 2005, 27, 1229-1254. [CrossRef]

97. Lindgren, T. Föränderlig Tillblivelse: Figurationen av det Posthumana Förskolebarnet; Malmö Universitet, Fakulteten för Lärande och Samhälle: Malmö, Sweden, 2018.

98. Davis, J.M.; Engdahl, I.; Otieno, L.; Pramling Samuelsson, I.; Siraj-Blatchford, J.; Valladh, P. The Gothenburg recommendations on education for sustainable development; Centre for Environment and Sustainability: Goethenburg, Sweden, 2008.

99. Engdahl, I. Early childhood education for sustainability: The OMEP world project. Int. J. Early Child. 2015, 47, 347-366. [CrossRef]

100. Davis, J.; Elliott, S. An orientation to early childhood education for sustainability and research: Framing the text. In Research in Early Childhood Education for Sustainability: International Perspectives and Provocations; Davis, J., Elliott, S., Eds.; Routledge: London, UK, 2014; pp. 1-17.

101. Boyd, D. Early childhood education for sustainability and the legacies of two pioneering giants. Early Years 2018, 38, 227-239. [CrossRef]

102. United Nations. Transforming our world: The 2030 agenda for sustainable development. In Proceedings of the General Assembley 70 Session, New York, NY, USA, 25 November 2015.

103. Chavan, M.; Yoshikawa, H. The Future of Our Children: Lifelong, Multi-generational Learning for Sustainable Development. Authored by the Thematic Group on Early Childhood Development, Education and the Transition to Work; U.N. Sustainable Development Solutions Network: New York, NY, USA, 2014.

104. Kemmis, S.; Mutton, R. Education for sustainability (EfS): Practice and practice architectures. Environ. Educ. Res. 2012, 18, 187-207. [CrossRef]

105. Wolff, L.-A.M.; Furu, A.-C. Hållbarhetspedagogik för finländska barnträdgårdslärarstudenter: Från begrepp till engagemang [Sustainability education for Finnish early childhood student teachers: From concepts to engagemnent]. Pedagog. Forsk. Sver. 2018, 23, 214-234.

106. Kemmis, S. Phronēsis, experience, and the primacy of praxis. In Phronesis as Professional Knowledge; Brill Sense: Leiden, Germany, 2012; pp. 147-161.

107. Mogren, A.; Gericke, N.; Scherp, H.-Å. Whole school approaches to education for sustainable development: A model that links to school improvement. Environ. Educ. Res. 2019, 25, 508-531. [CrossRef]

108. Taylor, A. Beyond stewardship: Common world pedagogies for the Anthropocene. Environ. Educ. Res. 2017, 23, 1448-1461. [CrossRef]

109. Taylor, A.; Pacinini-Ketchabaw, V.; Blaise, M. Children's Relations to the More-Than-Human World; SAGE Publications Sage UK: London, UK, 2012.

110. Haraway, D. Staying with the trouble for multispecies environmental justice. Dialogues Hum. Geogr. 2018, 8, 102-105. [CrossRef]

111. Haraway, D. When Species Meet; University of Minnesota Press: Minneapolis, MN, USA, 2008.

112. Haraway, D. Anthropocene, capitalocene, plantationocene, chthulucene: Making kin. Environ. Humanit. 2015, 6, 159-165. [CrossRef]

113. Rautio, P. Children who carry stones in their pockets: On autotelic material practices in everyday life. Child. Geogr. 2013, 11, 394-408. [CrossRef]

114. Karlsson Häikiö, T. Posthumanismi kasvatustieteessä-esiopetuksen jäljillä. Tieteessä Tapahtuu 2017, 35, 5.

115. Ritchie, J. Social, cultural, and ecological justice in the age the Anthropocene: A New Zealand early childhood care and education perspective. J. Pedagog. 2015, 6, 41-56. [CrossRef]

116. Nxumalo, F. Stories for living on a damaged planet: Environmental education in a preschool classroom. J. Early Child. Res. 2018, 16, 148-159. [CrossRef]

117. Barad, K. Posthumanist performativity: Toward an understanding of how matter comes to matter. Signs: J. Women Cult. Soc. 2003, 28, 801-831. [CrossRef]

118. Barad, K. Meeting the Universe Halfway: Quantum Physics and the Entanglement of Matter and Meaning; Duke University Press: Durham, NC, USA, 2007.

119. Stratford, R. Educational Philosophy, Ecology and the Anthropocene; Taylor \& Francis: Milton, UK, 2019.

120. Britton, S.; Haverkos, K.; Kutner, M.; Shume, T.; Tippins, D. Composing new understandings of sustainability in the Anthropocene. Cult. Stud. Sci. Educ. 2018, 13, 299-315. 
121. Castañeda, C. Figurations: Child, Bodies, Worlds; Duke University Press: Durham, NC, USA, 2002.

122. Rowson, J. Bildung in the 21st Century; CUSP: Guildford, UK, 2019.

123. Aristotle. The Nicomachean Ethics; D. Reidel: Dortrecht, The Netherlands, 1980.

124. Carroll, L. Through the Looking Glass and What Alice Found There; Penguin: London, UK, 2010.

125. Orr, D.W. Earth in Mind: On Education, Environment, and the Human Prospect; Island Press: Washington, DC, USA, 2004.

126. Sterling, S. Sustainability Education: Perspectives and Practice Across Higher Education; Taylor \& Francis: Milton, UK, 2010.

127. Naess, A. Ecology, Community and Lifestyle: Outline of an Ecosophy; Cambridge University Press: Cambridge, UK, 1990.

128. Taylor, A.; Pacini-Ketchabaw, V. Learning with children, ants, and worms in the Anthropocene: Towards a common world pedagogy of multispecies vulnerability. Pedagog. Cult. Soc. 2015, 23, 507-529. [CrossRef]

129. De Geus, M. Chapter 4 Utopian sustainability: Ecological utopianism. In The Transition to Sustainable Living and Practice; Emerald Group Publishing Limited: Bingley, UK, 2009; pp. 77-100.

130. Kant, I. Groundwork of the Metaphysics of Morals (Original Work Published 1785), 47th ed.; Cambridge Press: Cambridge, UK, 1997.

131. Kalland, M. Lapsen osallisuus päiväkodin arjessa [Children's participation in the daily life in preschools]. In Varhaiskasvatuksen Opettajan Kalenteri Vuodelle 2020-2021; Pakanen, A., Ed.; PS-kustannus: Jyväskylä, Finland, 2020; forthcoming.

(C) 2020 by the authors. Licensee MDPI, Basel, Switzerland. This article is an open access article distributed under the terms and conditions of the Creative Commons Attribution (CC BY) license (http://creativecommons.org/licenses/by/4.0/). 